\title{
СУЧАСНИЙ СТАН ТА НАПРЯМИ РОЗВИТКУ МАЛИХ ПІДПРИЕМСТВ У ПОЛТАВСЬКІЙ ОБЛАСТІ
}

\section{Рецензент - доктор економічних наук, професор В. В. Писаренко}

Досліджусться сучасний стан, аналізується динаміка основних показників розвитку малих підприємств у Полтавській області. Розглядається діяльність органів місиевої влади стосовно підвищення ефективності діяльності малих підприємств регіону. Виявлені проблеми розвитку малого підприємництва в області, означені напрями їх вирішення в нинішніх умовах господарювання.

Сектор малого підприємництва, як значущчий елемент розвитку ринкової економіки Полтавської області, перетворюється на важливий стабілізуючий фактор, імовірний засіб вирішення низки складних економічних і сочіальних проблем.

Ключові слова: малі підприємства, підприємницька діяльність, економічний розвиток, конкурентне середовище, регіональна політика.

Постановка проблеми. За сучасних умов значний вплив на економічне зростання України, вирішення актуальних соціально-економічних проблем має розвиток малих підприємств. Формуючи конкурентне середовище, забезпечуючи самозайнятість населення й оперативно реагуючи на зміни кон'юнктури, мале підприємництво надає ринковій економіці необхідної гнучкості. Мале підприємництво, завдяки своєму сприянню реалізації новітніх технічних і комерційних ідей, випуску наукомісткої продукції, виступає рушієм інноваційної діяльності. Крім того, виступаючи підгрунтям формування середнього класу, мале підприємництво сприяє елімінації соціальної напруги в суспільстві, забезпечує демократизацію ринкових відносин. Актуальність даної проблеми посилюється необхідністю визначення ймовірних економічно ефективних шляхів подальшого розвитку малого підприємництва в нашій країні.

Аналіз останніх досліджень та публікацій, у яких започатковано розв'язання проблеми. Серед сучасних вітчизняних дослідників проблем розвитку малих підприємств слід відзначити 3. Варналій, В. Виговську, Л. Мельник, П. Макаренка, Л. Наумову, С. Федоренко та інших $[2,3,6,7,10]$. Помітним явищем сучасної вітчизняної економічної науки стали регіональні дослідження, завдяки яким відкрилися можливості виявити особливості розвитку малого підприємництва на місцях, проаналізувати ефективність практичної реалізації заходів органами місцевої влади щодо розвитку малих підприємств. Дані питання отримали висвітлення в працях С. Бейгул, В. Ключник, О. Крайник та інших дослідників $[1,4,5]$. Однак питання розвитку малого підприємництва в регіонах у багатьох аспектах залишаються недостатньо розробленими. В умовах поглиблення регіоналізації економічних процесів із метою формування й практичної реалізації ефективної регіональної політики виникає потреба дослідження напрямів подальшого розвитку малого підприємництва, його територіальних особливостей.

Мета і завдання досліджень. Метою даної наукової розвідки є дослідження специфіки розвитку малих підприємств за сучасних умов у регіональному аспекті.

Завданням пропонованого дослідження є аналіз показників розвитку малих підприємств у Полтавській області й визначення стратегічних напрямів розвитку малого підприємництва.

Матеріали і методи досліджень. В основу дослідницької роботи покладений комплекс загальнонаукових та економічних методів і принципів: об'єктивізму, системності, багатофакторності. Дотримання принципів стало можливим завдяки використанню таких методів економічного дослідження, як аналітико-синтетичного, порівняльного, статистичного, розрахунковоконструктивного, моделювання, узагальнення.

Результати досліджень. Створений за попередні роки потужний потенціал малого підприємництва в Полтавській області нині дає змогу суттєво впливати на розвиток ринкових відносин. Зокрема, за результатами комплексної порівняльної оцінки діяльності регіонів Міністерством економіки щодо розвитку малого підприємництва та його підтримки на місцевому рівні, Полтавська область нині займає 11-13-е місця, перемістившись із 16-го [11].

Упродовж 2000-2010 рр. кількість малих під- 
приємств - у розрахунку на 10 тис. наявного населення - зросла на 9 одиниць і становила в 2010 р. 46 підприємств. У 2010 р., порівняно 32009 р., даний показник зменшився на 17 одиниць (27 \%) (табл. 1).

По районах і містах Полтавської області кількість малих підприємств у розрахунку на 10 тис. наявного населення суттєво відрізнялися. Зокрема, в 2010 р. найвищі показники спостерігалися в м. Полтаві (96 малих підприємств), м. Кременчуці (74). Найбільшою була кількість малих підприємств у Диканському (40), Пирятинському (34), Полтавському (30) районах; найменшою - в Миргородському (13), Семенівському (14), Козельщинському (15) районах [9, с. 221].

Рівень зайнятості на малих підприємствах (у відсотках до кількості населення у працездатному віці) упродовж 2005-2010 рр. був найвищим у 2006 р. (6,8\%); у 2010 р. становив 6,1\%. Найвищий рівень зайнятості на малих підприємствах у 2010 р. був зафіксований у Диканському (6,0 \%), Пирятинському (5,4 \%), Карлівському $(4,3 \%)$ районах. Того ж року частка кількості найманих працівників малих підприємств у загальній кількості найманих працівників по області становила $23 \%$, що на $8,4 \%$ більше, ніж у 2000 р. [9, с. 223,224$].$

При незначному зменшенні кількості найманих працівників на малих підприємствах за пері- од 2000-2010 рр. (4,4 \%) обсяг реалізованої ними продукції (робіт, послуг) збільшився у 9,5 разу. У 2010 р. малими підприємствами Полтавської області було реалізовано продукції, робіт і послуг на 12430,5 млн грн.

У загальній структурі витрат реалізованої продукції малими підприємствами Полтавської області у 2010 р. матеріальні витрати становили $22 \%$, вартість товарів і послуг, придбаних для перепродажу й реалізованих без додаткової обробки, $-59,7 \%$, амортизація - 2,5\%, витрати на оплату праці $-5,7$ \%, відрахування на соціальні заходи $-2 \%$, інші операційні витрати $-8,1 \%$. У 2010 р. малими підприємствами на одиницю реалізованої продукції витрачалося 98,9 грн, тобто на 0,2 грн більше, ніж у 2008 р. (табл. 2).

Чималий негативний вплив на результати діяльності малих підприємств Полтавщини мала світова економічна криза. У 2010 р. (порівняно 3 2009 р.) на 6,2 \% збільшилася питома вага малих підприємств, що одержали збиток. У 2010 р. переважна їх частина $(58,6 \%)$ отримала прибуток, проте збиток значної кількості малих підприємств спричинив збитковий фінансовий результат по регіону. Зокрема, в 2010 р. малими підприємствами області було отримано 629 млн грн прибутку, а фінансовий результат (сальдо) від звичайної діяльності до оподаткування склав $-144,8$ млн грн [9, с. 220].

\section{1. Основні показники розвитку малих підприємств Полтавської області}

\begin{tabular}{|c|c|c|c|c|}
\hline \multirow{2}{*}{ Показники } & \multicolumn{4}{|c|}{ Роки } \\
\cline { 2 - 5 } & 2000 & 2005 & 2009 & 2010 \\
\hline $\begin{array}{c}\text { Кількість малих підприємств на 10 тис. } \\
\text { наявного населення }\end{array}$ & 37 & 49 & 63 & 46 \\
\hline $\begin{array}{c}\text { Кількість найманих працівників на малих } \\
\text { підприємствах: }\end{array}$ & & & & \\
\hline - осіб & 55891 & 55061 & 55397 & 53422 \\
\hline - відсотків до попереднього року & 101,1 & 90,4 & 95,1 & 96,4 \\
\hline $\begin{array}{c}\text { Обсяг реалізованої продукції } \\
\text { (робіт, послуг): }\end{array}$ & & & & 12430,5 \\
\hline - млн грн & 1306,7 & 2206,6 & 11741,4 & 12,3 \\
\hline $\begin{array}{c}\text { відсотків до обсягу реалізованої продук- } \\
\text { ції (робіт, послуг) по області в цілому }\end{array}$ & 9,3 & 5,7 & 17,2 & 629,0 \\
\hline $\begin{array}{c}\text { Прибуток від звичайної діяльності до } \\
\text { оподаткування, млн. грн. }\end{array}$ & 121,8 & 113,5 & 555,8 & 773,8 \\
\hline $\begin{array}{c}\text { Збиток від звичайної діяльності } \\
\text { до оподаткування, млн грн }\end{array}$ & 94,4 & 144,4 & 652,8 & 41,4 \\
\hline $\begin{array}{c}\text { Питома вага підприємств, що одержали } \\
\text { збиток, відсотків до загальної кількості }\end{array}$ & 38,4 & 35,5 & 35,2 & $-144,8$ \\
\hline $\begin{array}{c}\text { Фінансовий результат від звичайної } \\
\text { дільності (сальдо), млн грн }\end{array}$ & 27,4 & $-30,9$ & $-97,0$ & \\
\hline
\end{tabular}

Джерело: [9, с. 220] 


\section{2. Структура операційних витрат реалізованої продукції малих підприємств} Полтавської області, \%

\begin{tabular}{|c|c|c|c|}
\hline Витрати & \multicolumn{3}{|c|}{ Роки } \\
\cline { 2 - 4 } & 2008 & 2009 & 2010 \\
\hline Матеріальні витрати & 18,6 & 18,2 & 22,0 \\
\hline $\begin{array}{c}\text { Вартість товарів та послуг, придбаних для } \\
\text { перепродажу та реалізованих } \\
\text { без додаткової обробки }\end{array}$ & 64,6 & 65,7 & 59,7 \\
\hline Амортизація & 1,6 & 2,2 & 2,5 \\
\hline Витрати на оплату праці & 4,9 & 5,1 & 5,7 \\
\hline Відрахування на соціальні заходи & 1,6 & 1,8 & 2,0 \\
\hline Інші операційні витрати & 8,7 & 7,0 & 8,1 \\
\hline $\begin{array}{c}\text { Операційні витрати на одиницю } \\
\text { реалізованої продукції, грн }\end{array}$ & 98,7 & 102,5 & 98,9 \\
\hline
\end{tabular}

Джерело: [8, с. 230-231; 9, с. 228-229]

3. Кількість діючих підприємств за організаційно-правовими формами господарювання у 2010 р.

\begin{tabular}{|c|c|c|}
\hline & \multicolumn{2}{|c|}{ Сільське господарство } \\
\cline { 2 - 3 } & усього & відсотків до загальної кількості \\
\hline Усього підприємств & 2368 & 100 \\
\hline Господарські товариства & 366 & 15,5 \\
\hline Приватні підприємства & 200 & 8,4 \\
\hline Виробничі кооперативи & 33 & 1,4 \\
\hline Фермерські господарства & 1650 & 69,7 \\
\hline Державні підприємства & 22 & 0,9 \\
\hline Підприємства інших форм \\
господарювання
\end{tabular}

Джерело: $[9$, с. 79$]$

У 2010 р. позитивний фінансовий результат отримали підприємства сільського господарства, мисливства, лісового господарства (114,9 млн грн), заклади транспорту та зв'язку (0,3 млн грн), фінансової діяльності (78,4 млн грн), освіти (0,2 млн грн), охорони здоров'я та надання соціальної допомоги (0,3 млн грн). Проте в 2010 р., порівняно з 2009 p., на Полтавщині збільшилася питома вага прибуткових малих підприємств лише в сфері фінансової діяльності (відповідно, 59,2 \% і 66,0 \% до загальної кількості підприємств); питома вага прибуткових підприємств сільського господарства, мисливства, лісового господарства, зокрема, зменшилася на $10,5 \%$ [9, c. 230$]$.

У 2010 р. найбільша кількість прибуткових підприємств (у відсотках до їх загальної кількості) функціонувала в Семенівському $(79,5)$, Котелевському $(76,7)$, Миргородському $(73,3)$ й Диканському $(71,3)$ районах. Найбільша кількість збиткових підприємств була зафіксована в Лохвицькому $(54,7$ \%), Гребінківському (47,6 \%), Машівському $(45,5 \%)$, Чорнухинському $(45,2 \%)$ районах $[9$, c. 231$]$.
Станом на 1 липня 2010 р. найбільшу кількість діючих сільськогосподарських підприємств за організаційно-правовими формами господарювання по районах і містах області становили фермерські господарства (1650) й господарські товариства (366), найменшу - державні підприємства (22) та виробничі кооперативи (33) (табл. 3).

Найбільша кількість фермерських господарств функціонувала в Глобинському (206), Полтавському (148), Козельщинському (122) районах, найменша - в Чорнухинському (13), Зіньківському (23), Оржицькому (24) районах [9, с. 85].

Із метою забезпечення сприятливих умов для розвитку малого підприємництва доцільно постійно удосконалювати методи й координувати функції управління цим процесом у системі дій центральних, регіональних і місцевих органів державної виконавчої влади. У Полтавській області рішенням четвертої сесії шостого скликання обласної ради від 30 березня 2011 р. була затверджена Комплексна програма розвитку малого підприємництва на 2011-2012 роки. Передбачається створення в малому бізнесі впродовж 
двох років 20-22 тисяч додаткових робочих місць, що дасть змогу працевлаштувати близько 230 тисяч працездатних осіб (близько 40 \% працездатного населення області). За прогнозними розрахунками на кінець 2012 року в області налічуватиметься 83-84 тисячі фізичних осібсуб'єктів підприємницької діяльності, близько 10 тисяч діючих малих підприємств, на яких (орієнтовно) будуть задіяні 60,5 тис. чоловік. Питома вага малих підприємств у обсягах реалізованої продукції становитиме 17,5\%, буде створено близько 3,5 тисяч додаткових робочих місць. Окрім цього, Програмою заплановане стабільне зростання надходжень до бюджетів усіх рівнів від суб'єктів підприємницької діяльності. Відповідно до проведеного моніторингу вони становили (з податком на найманих працівників): у 2009 р. - 577 млн грн, у 2010 р. 663 млн грн, прогноз на 2012 р. - 775-800 млн грн [11].

Iз метою усунення головного чинника суттєвого стримування розвитку малого підприємництва в області - високих відсотків при отриманні кредитних ресурсів від банківських установ у проекті Програми передбачений механізм відшкодування відсотків за кредитами суб'єктам підприємницької діяльності, які спроможуться реалізувати інноваційно-інвестиційні проекти за пріоритетними напрямами Програми.

Програма розвитку підприємництва в області - це соціальний проект, то ж іiі пріоритетами є модернізація та розбудова інфраструктури, інформаційно-консультаційна та фінансова підтримка. Упродовж 2011-2012 pp. із різних джерел фінансування на розвиток і діяльність малого підприємництва в Полтавській області планується залучення коштів у розмірі 940 млн грн [11]. Стратегічними напрямами розвитку малого підприємництва є наступні: підтримка розвитку

\section{БІБЛІОГРАФІЯ}

1. Бейгул С. Б. Регіональна політика розвитку малих підприємств у регіоні / С. Б. Бейгул // Економіка і регіон. - Науковий вісник ПолтНТУ ім. Юрія Кондратюка. - Полтава, 2005. - № 2. C. 66-70.

2. Варналій 3. С. Мале підприємництво: Основи теорії і практики / 3. С. Варналій - 2-ге вид., - К. : Знання, КОО, 2003. - 285 с.

3. Виговська В. В. Малий бізнес України: сучасний стан і тенденції розвитку / В. В. Виговська // Актуальні проблеми економіки. - 2009. - № 1. C. 59-63.

4. Ключник B. I. Ефективний розвиток підприєм- агропереробної галузі, фермерських, приватних селянських господарств; розвиток зеленого туризму й народних промислів; залучення підприємців до впорядкування полігонів побутових відходів у населених пунктах області на умовах довготермінової оренди; впровадження енергозберігаючих технологій; подальший розвиток сфери побутових послуг та торгівлі в сільських населених пунктах, віддалених від районних центрів.

Висновки. Однією з нагальних нерозв'язаних проблем розвитку малого підприємництва на загальнодержавному та регіональному рівнях в Україні залишається його державна підтримка. Подальші якісні трансформації й нові вектори розвитку малого підприємництва чималою мірою залежать від виваженості законодавчих реформ.

Проведений аналіз показав, що розвиток малого підприємництва в Полтавській області має, у цілому, динамічний характер. Найбільш значимими факторами його успішного функціонування $є$ законодавчий механізм підтримки малого підприємництва та діяльність органів місцевого самоврядування. Вироблення виваженої, результативної в короткостроковому і в довгостроковому періодах управлінської стратегії $\epsilon$ запорукою ефективного розвитку малого підприємництва на регіональному рівні.

Сектор малого підприємництва, як значущий елемент розвитку ринкової економіки Полтавської області, перетворюється на важливий стабілізуючий фактор, імовірний засіб вирішення низки складних економічних i соціальних проблем. Зокрема, практичне виконання Комплексної програми розвитку малого підприємництва у Полтавському регіоні на 2011-2012 рр. максимально сприятиме його пожвавленню, забезпечить сталі показники розвитку.

ницької діяльності в аграрному секторі регіонального АПК / В. І. Ключник, А. В. Ключник. Миколаїв : Вид-во І. Гудим, 2007. - 180 с.

5. Крайник О. П. Підприємництво як фактор регіонального економічного розвитку / О. П. Крайник // Регіональна економіка. - 2000. - № 4. C. 62-70.

6. Мельник Л. Ю. Аграрне підприємництво і держава: [монографія]. / Л. Ю. Мельник, П. М. Макаренко, О. А. Любович. - Дніпропетровськ : Пороги, 1999. - 259 с.

7. Наумова Л. Ю. Розвиток малого і середнього підприємництва як фактор фінансової стабіліза- 
ції в державі / Л. Ю. Наумова // Фінанси України. - 2001. - № 11. - С. 24-29.

8. Статистичний щорічник Полтавської області за 2008 рік / За ред. Т. Л. Бугайченко // Державний комітет статистики України, Головне управління статистики у Полтавській області, 2009. $421 \mathrm{c}$.

9. Статистичний щорічник Полтавської області за 2010 рік / За ред. Л. М. Безхлібняк // Державний комітет статистики України, Головне управ- ління статистики у Полтавській області. - Полтава : Полтавський літератор, 2011. - 408 с.

10. Федоренко C. В. Проблеми розвитку малого бізнесу в Україні / С. В. Федоренко // Економіка та держава. - 2008. - № 5. - С. 4-6.

11. Перспективи розвитку малого бізнесу в Полтавській області у 2011-2012 роках [Електронний pecypc]. - Режим доступу: http://www.admpl.gov.ua/main/publication/content/11587.htm 